\title{
The Effect of The Using of Learning Multimedia and Motivation to The Result of Arabic Learning
}

\author{
Zohra Yasin, Rahmin T. Husain \\ zohrayasin@iaingorontalo.ac.id, rahmin.husain@gmail.com
}

IAIN Sultan Amai Gorontalo,Gorontalo, Indonesia

\begin{abstract}
: this research aims to know the influence of the using of learning multimedia and motivation to the result of students' Arabic learning in the class. The research method used in this research was an experiment research by using treatment with levels designs $2 \times 2$, data were collected through the test and motivation questionnaire. The data analysis in this research used variance analysis test (ANAVA) in two directions $(2 \times 2)$ by using $\mathrm{F}$ test on the significance level $\alpha=0,05$ and an advance test by using Scheffe test. The result of the research showed that the students who learned by using learning multimedia had higher average scores than compared with the students who didn't use learning multimedia. Study motivation of students who learned by using learning multimedia had average scores which were higher than the students who didn't use learning multimedia in their learning process in the class. There were influences of interaction between the using of learning multimedia and motivation to study to the learning result of students' Arabic learning. At the group of students who had high learning motivation, the result of students' Arabic learning which used learning multimedia was higher than the result of students' Arabic learning which didn't use learning multimedia.

Keywords: Learning Multimedia, Motivation, Learning Result
\end{abstract}

\section{INTRODUCTION}

One of the latest developments in education technology is the use of multimedia in the learning process. Multimedia technology can give big and deep impression at the field of education and communication. In the context of education, teacher uses the media (such as: simulation, animation, video, and another form of visualisation) for helping to explain the material because this kind of media can add the the transition of the abstract becoming more concrete to represent the cognition of students[1]. By utilizing the multimedia feature in the learning process, it is expeted that student can be able to accept the visualisation, voice, and verbal communication from the learning material informasi clearly so it is possible to build cognition through the received information[2].

The use of multimedia is a background of the human cognitive theory whih can be able to give the effect in remembering information easily which is processed through the message[3][4]. Multimedia provide facility and easiness in serving the information for the students in learning process and obtain the optimal learning result so it is effective to be used in the learning process[5][6]. Multimedia have many obvious advantages in the learning process such as it is informative and interesting, easy and safe in the usage and also able to increase the teacher's efficiency in teaching in the class[7][8]. This thing shows that multimedia have important role in the learning process and also have special and unique attractiveness and able to help teacher in conducting the learning process and optimally increasing the learning result.

Some researches in Indonesia show the advantages of the using of learning multimedia in increasing the students' leraning result. Some of those researches as conducted by Radityan, Kuntadi \& Kumaro (2014) that showed the significant effect of multimedia in the students' learning result [9]. Afriani, Jalmo \& Yolida (2014) also conducted a research that showed that a learning process which was conducted by using interactive multimedia had significant effects in 
increasing the learning result and activity of the student [10]. Rudiawan, Hamidah \& Komaro stated that a learning that used multimedia was very effective in improving students' learning result [11]. Kartikasari stated that the implementation of learning media based on multimedia has positive effect to the improvement of motivation and learning result of the students[12].

Some results of the research above show that the use of learning multimedia in learning process is very important and crucial, and the importance of using learning multimedia is also found in the Arabic learning. Language aspect can't be separated from the analysis of behaviour (behaviour that should be studied and the condition of study behaviour that should be mastered by students in the learning process and also the change of behaviour after having a learning process).

The Arabic learning in Indonesia still faces some problems and challenges, so the purpose of the ideal Arabic learning which is not implemented comprehensively. Arabic is not popular to be learned by students if it is compared with English. That opinion appears among people in society because people are not familiar with Arabic language and also there is a belief among people which consider that Arabic is very difficult to be studied and to be understood because it needs the understanding of Arabic letter writing and reciting. Besides that, teaching Arabic is not easy, it needs very great efforts from teacher and also requires supportable facilities. This thing can be proved from the result of students' learning that still is very low.

The low students' learning result was showed by the score of students which still under the standard (KKM) that can be caused by some factors. Generally, the factors that can influence the students' learning result can be divided into two, those are: intrinsic factor (from inside the students) and extrinsic factor (from outside the students). The factor that comes from the inside of students such as the body health, learning interest, intelligence, learning motivation, student's gift, cognitive ability, and the attitude of students to the lesson subject. Whereas, the factors that come from outside the student are family, social and physical environment, curriculum, teaching method, teacher, learning media, and facilities.

One of the external factors that influence the students' learning result is the use of learning media. Learning media is a device which can be used in delivering information to stimulate students to learn in learning process. By the presence of media in the learning process, it is expected that the elarning process will be easier for student and teacher, because learning media can solve the problems of space and time in learning process. The use of learning media also can give motivation for students to study hard. However, the use of learning media is still not optimal in teaching and learning process in classroom. The problem that also faced by Arabic language teacher is the unnefficient using of learning media in the learning process in the class. Generally, it is caused by some factors such as limited preparation time, there are some difficulties in searching the appropriate media, unavailable cost, or some other reasons. Actually, those things don't need to appear if the knowledge about some various learning meadia, characteristics, and also the ability is well known by the teachers. There are some various kinds of media so they can be utilized as the condition, appropriate time, as the condition of financial ability, or as the delivered material. Every kind of media has characteristic and ability in delivering message and information. Teacher still focuss on the book or modul which is given to the students and it makes students have very low spirit and interest in learning and practicing Arabic.

Besides some external factors that influence students' learning result, there are also internal factors. One of the internal factors that influence students' learning result in learning Arabic is learning motivation. Learning motivation is an encouragement that comes from inside or outside a person so that it can lead students to do some learning activities. The role of motivation is very important to encourage students to get good learning results in the learning 
process. The learning motivation can cause learning spirit inside students which will make students achieve an optimal learning result. The motivation of each student in learning Arabic in the class is very various. There are some students with very great enthusiasm for learning Arabic which is shown with high enthusiasm in doing the tasks given, some are low motivated and complain when teacher give them assignments. Besides that, there are some students who still think that Arabic is a difficult subject so the motivation of students to learn Arabic is very low. If the motivation to learn Arabic is low and the use of learning media is not optimal, the learning result achieved will be low.

The current problem faced by Arabic teachers is the inefficient using of learning media in the learning process in the class. Generally, that thing was caused by some various reasons, such as limited preparation time, the difficulty in finding the right media, no fees available, or the other reasons. Actually, that thing does not need to appear if teachers have enough knowledge of some various learning media, characteristic, and the ability of each student is known by the teacher. There are some varieties and types of media so they can be utilized according to the condition, time, the condition of financial ability, and material given in the class. Each kind of media has the characteristic and ability in delivering message and information. The teacher still focuss on the book or module given to students, so that the enthusiasm of the students to practice becomes low. Therefore, this research is considerably important, urgent and it needs to be proven that there is an influence of multimedia use and learning motivation on student learning result in learning Arabic.

\section{METHOD}

\section{A. Research Design}

This research is an experimental research with the design of Treatment by Levels Designs $2 \times 2$, to investigate the effect of independent variables and their interaction with attribute variables on the dependent variable. The independent variable is learning media (A) which consists of the using of multimedia learning (A1) and not using multimedia learning (A2). Attribute variable in this research is learning motivation (B) consisting of high motivation (B1) and low motivation (B2). The free variable is the learning result of students (Y) in learning Arabic as presented in table I:

TABEL I

\section{EXPERIMENT RESEACRH DESIGN}

\begin{tabular}{ccc}
\hline \multirow{2}{*}{$\begin{array}{c}\text { Motivation } \\
(\mathbf{B})\end{array}$} & \multicolumn{2}{c}{ A } \\
\cline { 2 - 3 } & $\begin{array}{c}\text { Using Learning } \\
\text { multimedia }\left(A_{1}\right)\end{array}$ & $\begin{array}{c}\text { Not Using Learning } \\
\text { Multimedia }\left(A_{2}\right)\end{array}$ \\
\hline $\operatorname{High}\left(\mathrm{B}_{1}\right)$ & $\mathrm{A}_{1} \mathrm{~B}_{1}$ & $\mathrm{~A}_{2} \mathrm{~B}_{1}$ \\
\hline $\operatorname{Low}\left(\mathrm{B}_{2}\right)$ & $\mathrm{A}_{1} \mathrm{~B}_{2}$ & $\mathrm{~A}_{2} \mathrm{~B}_{2}$ \\
\hline
\end{tabular}

\section{Explanation :}

$\mathrm{A}_{1}=$ the group of students who learn by using learning multimedia.

$\mathrm{A}_{2} \quad=$ the group of students who learn not by using learning multimedia.

$\mathrm{B}_{1} \quad=$ the group of students who has high motivation.

$\mathrm{B}_{2}=$ the group of students who has low motivation

$\mathrm{A}_{1} \mathrm{~B}_{1}=$ the group of students with high motivation who learns by using learning multimedia.

$\mathrm{A}_{2} \mathrm{~B}_{1}=$ the group of students with high motivation who learns not by using learning multimedia. 
$\mathrm{A}_{1} \mathrm{~B}_{2}=$ the group of students with low motivation who learns by using learning multimedia.

$\mathrm{A}_{2} \mathrm{~B}_{2}=$ the group of students with low motivation who learns not by using learning multimedia.

\section{B. Population and Sample}

Penelitian ini dilaksanakan pada salah satu sekolah menengah pertama (Madrasah Tsanawiyah) di Provinsi Gorontalo. Subjek penelitian adalah seluruh siswa Kelas VIII yakni $\mathrm{VIII}_{1}$, Kelas $\mathrm{VIII}_{2}$, Kelas $\mathrm{VIII}_{3}$, Kelas $\mathrm{VIII}_{4}$, Kelas VIII5, Kelas VIII 6 , dan Kelas VIII berjumlah 208 dengan teknik random sampling menggunakan sistem undian diperoleh sampel penelitian adalah yaitu kelas $\mathrm{VIII}_{2}$ dengan 35 peserta didik sebagai kelas eksperimen dan kelas $\mathrm{VIII}_{3}$ dengan 35 peserta didik sebagai kelas kontrol. This research was conducted in one junior high school (Madrasah Tsanawiyah) in Gorontalo Province. The research subjects were all VIII Grade students at the school, those were: VIII1 class, VIII2 class, VIII3 class, VIII4 class, VIII5 class, VIII6 class, and VIII7 class with total 208 students and used a random sampling technique by using the lottery system and the rsearch sample classes were obtained, they were: VIII2 class with 35 students as class experiment and VIII 3 class with 35 students as a control class.

\section{Data Collection Technique}

The data were collected through the test in form of multiple choice tests which were used on the pre-test and post-test. Questionnaires were used to collect data about the motivation of students and the students'answers to the questionnaire showed the motivation of students. Before the instrument was used, the instrument was tested and validated by experts and the reliability of the instrument using Cronbach's Alpha obtained a valid and reliable instrument for 30 items of questions and 35 items for motivation questionnaire.

\section{Data Analysis}

Data analysis technique in this research was preceded by analysis assumption tests, they were: data normality test and homogeneity test. Then, it was continued by the hypothesis examination test conducted by variance analysis test (ANAVA) two dirrections (2x2) with F test ot the significanve level $\alpha=0,05$ and the further test conducted by using Scheffe test.

\section{RESULT AND DISCUSSION}

To prove the difference in Arabic learning result between students who learn with multimedia learning with students who learn not to use multimedia learning, previously it was conducted the comparison of the score data from the pre-test and post-test results between the highest score, lowest score, mean, median, modus and the standard deviation of the experimental class and control class as presented in table II: 


\begin{tabular}{ccccc}
\hline Test & \multicolumn{2}{c}{ Pre Test } & \multicolumn{2}{c}{ Post Test } \\
\hline Class & Exper-group & Control-group & Exper-group & Control-group \\
\hline $\mathbf{N}$ & 35 & 35 & 35 & 35 \\
\hline Highest Score & 77 & 80 & 97 & 83 \\
\hline Lowest Score & 53 & 50 & 73 & 60 \\
\hline Gain Score & 71,31 & 70,48 & 20 & 76,14 \\
\hline Median & 73 & 70 & 90 & 77 \\
\hline Mode & 73 & 70 & 93 & 77 \\
\hline Standard Deviation & 4,957 & 6,085 & 6,546 & 5,652 \\
\hline
\end{tabular}

The pre-test value of the experimental class obtained 77 as the highest score and the lowest score was 53, while the post-test result obtained 97 as the highest score and the lowest score obtained was 73. While the pre-test score for the control class class obtained 80 as the highest score and the lowest score was 50, while the post-test score obtained 83 as the highest score and the lowest score was 60 . The pre-test score of the control class obtained 70.48 as the average score, while the post-test average score was 76.14. In the experimental class the average score increased significantly where the average of pre-test score obtained was 71.31 and the average of post-test score was 88.74 , so that there was an increase in the average learning result of pre-test and post-test from the experimental class and control class.

To prove whether there are differences in Arabic learning result between learners who learn with multimedia learning and students who learn which no use of multimedia learning, data requirement is first tested which consist of data distribution normality test and variant homogeneity test. The conclusion of testing the normality distribution and homogeneity test qualify the assumption of normality and the sample variant was omogeny where there were no differences in variance between the two groups tested. Furthermore, the hypothesis was tested to see the interaction effect of using multimedia learning and learning motivation on Arabic learning result of students based on Anava (Anava 2x2) calculation results as summarized in table III below:

TABEL III

SUMMARRY OF ANAVA CALCULATION

\begin{tabular}{cccccc}
\hline Variance Soourcei & JK & DK & RK & $\mathbf{F}_{\text {count }}$ & $\mathbf{F}_{\text {table }}$ \\
\hline Column (K) & 2731,8 & 1 & 2731,8 & 74,01 & 3,14 \\
\hline Row (B) & 116,5 & 1 & 116,5 & 3,16 & 3,14 \\
\hline $\begin{array}{c}\text { Row and Column } \\
\text { (BK) }\end{array}$ & 5716,7 & 1 & 5716,7 & 154,88 & 3,14 \\
\hline Deep (d) & 2362,24 & 64 & 36,91 & & \\
\hline Total (T) & 10927,24 & 67 & 78,07 & & \\
\hline
\end{tabular}

The result of the analysis of the two paths variance between columns obtained by the value of $F_{\text {count }}=74.01$ greater than $F_{\text {table }}=3,14$ at the significance level $\alpha=0,05$. This meant that the hypothesis that there were differences in Arabic learning result between students who learn with multimedia learning with students who learn not to use multimedia learning was received significantly, where the learning result of Arabic students who learn using multimedia learning was higher than the learning result of students who learn by not using multimedia learning. The result of the analysis of the two paths variance between column and row obtained by the value of $F_{\text {count }}=116,5$ greater than $F_{\text {table }}=3,14$ at the significance level $\alpha$ $=0,05$. This meant that the null hypothesis $\left(\mathrm{H}_{0}\right)$ which stated that there was an influence of interaction between the use of multimedia learning and learning motivation on the learning result of Arabic students was received significantly. 
The testing of the first hypothesis to know whether there were differences in Arabic learning result between students who learn with multimedia learning $\left(A_{1}\right)$ with students who learn not by using learning multimedia $\left(\mathrm{A}_{2}\right)$ obtained results as presented in table IV:

TABEL IV

THE TEST OF THE DIFFERENCE OF STUDENTS' LEARNING RESULT

\begin{tabular}{cccccc}
\hline Group & Average & $\begin{array}{c}\text { Significance } \\
\text { Level }\end{array}$ & F count & F table & Decision \\
\hline $\mathrm{A}_{1}$ & 90,76 & 0,05 & 74,01 & 3,14 & $\begin{array}{l}\mathrm{H}_{0 \mathrm{~A}} \text { refused } \\
\mathrm{A}_{2}\end{array}$ \\
77,00 & 0,05 & & & $\mathrm{H}_{1 \mathrm{~A}}$ accepted \\
\hline
\end{tabular}

The calculation result showed the average score of the learning result of students who learn by using multimedia learning $\left(\mathrm{A}_{1}\right)$ was 90,76 higher than the average score of learning result of Arabic students who learned by not using multimedia learning $\left(\mathrm{A}_{2}\right)$ which was 77 , where the learning result of Arabic students who learned by using multimedia learning was higher than the learning result of students who learned by not using multimedia learning. The testing of the second hypothesis was to know whether there were any influence of interaction between the use of multimedia learning and learning motivation on students' Arabic learning result as presented in table $\mathrm{V}$ :

TABEL V

INTERACTION EFFECT TEST

\begin{tabular}{|c|c|c|c|c|c|}
\hline Group & Average & $\begin{array}{c}\text { Significance } \\
\text { Level }\end{array}$ & $\mathbf{F}_{\text {count }}$ & $F_{\text {table }}$ & Decision \\
\hline $\mathrm{A}_{1} \mathrm{~B}_{1}$ & 90,76 & 0,05 & \multirow{4}{*}{154,88} & \multirow{4}{*}{3,14} & \multirow{4}{*}{$\begin{array}{c}\mathrm{H}_{0 \mathrm{AB}} \\
\text { refused } \\
\mathrm{H}_{1 \mathrm{AB}} \\
\text { accepted }\end{array}$} \\
\hline $\mathrm{A}_{2} \mathrm{~B}_{1}$ & 77,00 & 0,05 & & & \\
\hline$A_{1} B_{2}$ & 87,06 & 0,05 & & & \\
\hline $\mathrm{A}_{2} \mathrm{~B}_{2}$ & 75,47 & 0,05 & & & \\
\hline
\end{tabular}

At the Anava table, the value of $F_{\text {count }}=154,88$ was greater than $F_{\text {table }}=3,14$ at the significance level $\alpha=0,05$, then the null hypothesis (H0) was rejected. This meant that there was an interaction effect between the use of multimedia learning and the motivation to learn on the result of learning Arabic. The result of the calculation of the average score of learning result from the group of students with high motivation who learned by using multimedia learning $\left(A_{1} B_{1}\right)$ was 90.76 and the average score of learning result of group with low motivation students who learned by not using multimedia learning $\left(A_{1} B_{2}\right)$ was 87.06. While the average score of learning result from the group of students with high motivation who learned by not using learning multimedia $\left(\mathrm{A}_{2} \mathrm{~B}_{1}\right)$ was 77.00 and the average score of learning result from the group of students with low motivation and learned by not using multimedia learning $\left(\mathrm{A}_{2} \mathrm{~B}_{2}\right)$ was 75.47. Then, it could be concluded that in the group of students who had high learning motivation, the learning result of Arabic students who learned with multimedia learning were higher than the learning result of Arabic students who learned with no use of multimedia learning. Likewise in the group of students who had low learning motivation, the learning result of Arabic students who learned with multimedia learning were higher than the learning result of Arabic students who learned with no use of multimedia learning.

The testing of the third hypothesis was to prove whether there were differences in the results of learning Arabic in the group of students with high learning motivation between 
students who learned by using multimedia learning with students who do not use multimedia learning. That was conducted to determine the meaningfulness of the interaction among research variables by using advanced analysis test (Scheffe Test) with two types of comparison, they were: the average comparison between cells in the same row, and the average comparison between cells in the same column. Whereas for inter-row meaning, it was not necessary to do post-anava comparison because there were only two variables obtained as presented in table VI:

TABEL VI

THE DIFFERENCE OF $\mathrm{A}_{1} \mathrm{~B}_{1}$ AND $\mathrm{A}_{2} \mathrm{~B}$

\begin{tabular}{cccccc}
\hline Group & Average & $\begin{array}{c}\text { Significance } \\
\text { Level }\end{array}$ & $\mathbf{F}_{\text {count }}$ & $\mathbf{F}_{\text {table }}$ & Decision \\
\hline $\mathrm{A}_{1} \mathrm{~B}_{1}$ & 90,76 & 0,05 & 34,24 & 3,14 & $\mathrm{H}_{0}$ refused \\
$\mathrm{A}_{2} \mathrm{~B}_{1}$ & 77,00 & 0,05 & $\mathrm{H}_{1}$ accepted \\
\hline
\end{tabular}

Based on the result of the calculation of further analysis using the Scheffe Test, the value $F_{\text {count }}=34,24$ was greater than $F_{\text {table }}=3,14$ at the significance level $\alpha=0.05$, then the null hypothesis $\left(\mathrm{H}_{0}\right)$ was rejected. This meant that in the group of students who had high motivation, the learning result of Arabic students who learned by using multimedia learning $\left(A_{1} B_{1}\right)$ was higher than the learning result of Arabic students who learned by not using learning multimedia $\left(\mathrm{A}_{2} \mathrm{~B}_{1}\right)$.

From the marginal average, showed that the average learning result of Arabic students who learned by using multimedia learning was higher than the average learning result of students who learned by not using multimedia learning, where the calculation results showed that the average score of learning result in the group of students who had high motivation to learn by using learning multimedia as 90.76 was higher than the average score of learning result in group of students who had high learning motivation by not using learning multimedia which was 77,00 .

The testing of the fourth hypothesis was whether there were differences in the result of learning Arabic in the group of students with low learning motivation between students who learned with multimedia learning with students who learned wuth no use of multimedia learning to determine the meaningfulness of interaction among research variables using advanced test analysis (Scheffe Test) and obtained results as shown in table VII:

TABEL VII

THE DIFFERENCE OF $\mathrm{A}_{1} \mathrm{~B}_{2}$ DAN $\mathrm{A}_{2} \mathrm{~B}$

\begin{tabular}{cccccc}
\hline Group & Average & $\begin{array}{c}\text { Significance } \\
\text { Level }\end{array}$ & $\mathbf{F}_{\text {count }}$ & $\mathbf{F}_{\text {table }}$ & Decision \\
\hline $\mathrm{A}_{1} \mathrm{~B}_{2}$ & 87,06 & 0,05 & 10,67 & 3,14 & $\begin{array}{l}\mathrm{H}_{0} \text { refused } \\
\mathrm{A}_{2} \mathrm{~B}_{2}\end{array}$ \\
\hline
\end{tabular}

Based on the result of the calculation of further analysis using the Scheffe Test, it was obtained the value of $F_{\text {count }}=10,67$ was greater than $F_{\text {table }}=3,14$ at the significance level $\alpha=$ 0,05 , then the null hypothesis $\left(\mathrm{H}_{0}\right)$ was rejected. This meant that in the group of students who had low motivation, the learning result of Arabic students who learned by using multimedia learning $\left(\mathrm{A}_{1} \mathrm{~B}_{2}\right)$ was better than the group of students with low motivation who learned by not using learning multimedia $\left(\mathrm{A}_{2} \mathrm{~B}_{2}\right)$. 
These findings were consistent with the finding from the rsearch conducted by Srivastava that found the use of multimedia as a teaching tool was proven to help students in providing additional opportunities for learning and were very enthusiastic to follow the learning process in the class [13]. This finding showed that multimedia learning was conducted in the classroom by using computers to create and combined text, graphics, audio, moving images to convey more interesting learning material, more interactive, the amount of teaching time can be reduced, the quality of learning of students could be improved and the learning process could be conducted anywhere and anytime, and the learning attitudes of students could be improved.

The use of multimedia was very effective because multimedia effect in learning process made students easier to remember when text or narration and animated images were shared. The process of integrating animated text, image and also the relevant video was a key step in a meaningful learning. Gilakjani used multimedia equipments in learning was able to find the best way for students to learn effectively and also teachers in teaching efficiently [14]. By using multimedia, students could see, heared and even interacted with eac other. So that, the involvement of students' senses in the use of learning multimedia was more effective than when they learned with no using of learning multimedia but only using textbook and image.

The use of multimedia made students more interested in participating in learning, students seemed enthusiastic with the process conducted independently through an attractive and interactive display. This was in line with the research by Khazai \& Moradi which showed that multimedia had positive effect on learning and building interaction with students [15]. The interest of students in multimedia caused the learning process in the class that was more live and more presentative, so that multimedia helped many students and teachers in the learning process.

Based on the finding of the research related to the effect of multimedia on learning research, it could be concluded that the use of multimedia learning made the learning experience more concrete than learning that did not use multimedia learning. The using of multimedia learning in the elarning process had influenced the learning reseacrh of students. This meant that in the use of atrractive multimedia learning activities made students be able to improve the learning result because learning activities attracted students' attention and they would not be bored in following the learning activities until the end.

Furthermore, the finding of the study related to the motivation of students in learning Arabic indicated that the motivation score of students who learned by using learning multimedia had an average score 161,54 of the maximum total score which was 175 . The average was higher than the average score of the motivation of the students who learned by not using multimedia learning which was 146,37 . This meant that the motivation of students who learned by using multimedia learning was higher than the motivation of students who learned by not using multimedia learning. An increase in motivation was caused by several factors. The factors according to the researcher based on the motivational indicators that have been aomposed as follow:

First, students found new thing, which could increase their curiosity. If their daily learning did not use multimedia, so that the learning in this research used multimedia learning in the form of multimedia presentation. The combination of images, motions and sounds improved students' interest in learning, while at the same time they made students becoming more enthusiastic in completing the assignments. Second, teachers were able to build students' self-confidence, and also the creative and optimistic attitudes of students by conducting a productive learning process. The teacher was able to provide feedback to students, so that 
students actively participated in the learning process. In this case, students became more active because of their interest in the feedback provided by the teacher.

Students with high motivation have a high learning desire. With the desire to always improve their abilities. Students who learned by using multimedia presentation which was novelty media could provide good stimulus, then it could increase the excitement in the learning process. Furthermore, learning multimedia could influence the learning result of Arabic students who had high motivation. This showed that the use of multimedia learning with the support of students 'good learning motivation further improved students' learning result. Students with high learning motivation had better learning result compared to students who had low learning motivation.

There were differences in Arabic learning result between students who learned by using multimedia learning with students who learned with no using of multimedia learning was possible to exist because in the multimedia learning process had advantages such as subject matter displayed visually with the presence of animation so that students were more impressed by the benefits of learning material. This certainly caused the group of students who learned by using multimedia learning to have better learning result than not by using multimedia learning.

The research by Hanim, Sumarmi \& Amiruddin stated that there was a significant effect on the use of multimedia interactive learning remote sensing to the students' learning result [16]. The effect of the use of multimedia learning on student learning result with an effect value of $1,61>0,8$ which was categorized as a large measure of effectiveness. This showed that multimedia usage was very effective because the multimedia influence in learning made students easier to remember when text or narration and animated images were shared. The process of integrating animated text, image and also relevant video was a key step in a meaningful learning process. This process could be facilitated with the use of multimedia in learning rather than just with text that affected the acquisition of learning result. By using multimedia students could see, heared and even interacted with each other, so that the involvement of students' senses in the use of interactive multimedia learning was more than just using textbook and picture. The use of multimedia made students became more interested in participating in learning, students seem enthusiastic with the process conducted independently through an attractive interactive display.

Some research results above, proved that the use of learning multimedia affected students' learning result. The interest of students in multimedia caused by learning process conducetd was more live and presentative so that multimedia helped many students and teachers in the learning process. The use of learning multimedia had several advantages, such as it could show display text, audio, image, animation or video in the same time. Some materials that require detailed explanation, could be displayed through the presentation of animation or video. The use of animation media in learning would make students easier to visualize material that was considerably difficult. Animation could explain abstract concepts into concrete concept, in this case clearly not found in textbooks or worksheets. The use of multimedia in learning was very effective and efficient, especially if they were presented properly created a significant impact on learning result. Learning using multimedia significantly helped students to access knowledge and information in learning, enhancing the learning experience and effectively enhancing the accessibility of the learning environment for group of students in exploring subject matter. Based on the description above, it was clear that the use of learning multimedia had an effect on learning result was proven to be true.

The research finding also found that the learning result of students who learned by using multimedia learning in group of students who had high motivation was better than the group 
of students who learned by not using multimedia learning. For students' learning motivation could create the spirit of learning so that students were encouraged to learn. Students learned with pleasure because they were motivated. In learning without using print media, the teacher could only provide an explanation once, so that not many students could interact directly with the teacher. If students who still did not understand the material, then the students must study alone or study with friends in group.

This study proved that in learning Arabic, if learning process used multimedia learning, the learning result of Arabic students were better compared to learning that did not use multimedia learning. This was seen from the average acquisition of learning result by using multimedia learning better than by not using multimedia learning. The differences in learning result were caused by learning that did not use less multimedia learning, there was a reciprocal relationship between the media and students, while in the use of multimedia learning was more interesting, because in multimedia contained diverse material accompanied by picture, sound and movement. Multimedia learning created reciprocal relationship between media and students, students became more enthusiastic and not bored in participating in learning. This happened because multimedia learning was designed as an interactive media, so that its appearance fulfilled the function of informing the messages. The use of multimedia learning that actively involved students in the learning process. By using multimedia learning that was audiovisual in nature showed that learning had its own attraction for students and also motivated students to learn. Besides that, multimedia learning reduced boredom in learning, and also increased the resilience of memory to the learning object that students learn.

The limitation of this study was this research only examined the effect of using multimedia learning and learning motivation on learning result. Noted that learning results were not influenced by just one factor. Basically there are many factors that influenced learning result. The factors that influence learning result, including internal factors (creativity, level of intelligence, emotional level, motivation, and students' interests) and external factors (curriculum, social environment, natural environment and the others). For this reason, further research was needed to determine the influence of these factors in learning Arabic.

\section{CONCLUSSION}

The use of multimedia learning and learning motivation had an influence on the learning result of students in learning Arabic. The most important thing in the criteria for media selection was the selection of media that matched the objective, the subject matter to be taught. The difference in the learning result of Arabic between students who learned with multimedia learning with students who learned with no using of multimedia learning had the implication that teachers who taught by using multimedia learning produced better learning result than teachers who did not use multimedia learning. There were differences between students who had high motivation and low motivation towards the learning result of Arabic students. This implied the higher the learning motivation of students, the higher the learning result of students, whereas the lower the motivation of students, the lower the learning outcomes of students in learning Arabic. There was an interaction between the use of multimedia learning and motivation to learn the learning result of Arabic students, this implied that if the teacher did not use multimedia learning and students had low motivation in learning, the learning result of students was also low.

\section{REFERENCES}

[1] M. Barak, T. Ashkar, and Y. J. Dori, "Computers \& Education Learning science via animated movies: Its effect on students' thinking and motivation," Comput. Educ., 
vol. 56, no. 3, pp. 839-846, 2011.

[2] L. Y. Wu and A. Yamanaka, "Exploring the effects of multimedia learning on preservice teachers 'perceived and actual learning performance: the use of embedded summarized texts in educational media," EMI. Educ. Media Int., vol. 50, no. 4, pp. 291-304, 2014.

[3] S. V Murphy and A. Atala, "3D bioprinting of tissues and organs," . Nat. Biotechnol., vol. 32, no. 8, pp. 773-785, 2014.

[4] X. Zhang and X. Zhang, "A study of the effects of multimedia dynamic teaching on cognitive load and learning outcome," EURASIA J. Math. Sci. Technol. Educ., vol. 12, no. 11 , pp. 2851-2860, 2016.

[5] S. Aloraini, "The impact of using multimedia on students ' academic achievement in the College of Education at King Saud University," J. King Saud Univ. - Lang. Transl., vol. 24, no. 2, pp. 75-82, 2012.

[6] G. O. Ilhan and Ş. Oruç, "Effect of the use of multimedia on students 'performance : A case study of social studies class," Acad. J., vol. 11, no. 8, pp. 877-882, 2016.

[7] X. Xu, "Study on Effective Using of Multimedia Teaching System and Enhancing Teaching Effect," Int. J. Emerg. Technol. Learn., vol. 12, no. 6, pp. 187-195.

[8] S. Subandi, S. Subandi, C. Choirudin, M. Mahmudi, N. Nizaruddin, and H. Hermanita, "Building Interactive Communication with Google Classroom," Int. J. Eng. Technol., vol. 7, no. 2.13, pp. 460-463, Apr. 2018.

[9] F. T. Radityan, I. Kuntadi, M. Komaro, D. Pendidikan, T. Mesin, and U. P. Indonesia, "Pengaruh Multimedia Interaktif Terhadap Hasil Belajar Siswa Pada Kompetensi Perbaikan Differential," J. Mech. Eng. Educ., vol. 1, no. 2, pp. 239-245, 2014.

[10] R. Afriani, T. Jalmo, and B. Yolida, "Pengaruh Pembelajaran Multimedia Interaktif Terhadap Hasil Belajar Siswa," J. Bioterdidik Wahana Ekspresi Ilm., vol. 2, no. 6, pp. $1-2$.

[11] D. Rudiawan, I. Hamidah, and M. Komaro, "Pengaruh multimedia model tutorial terhadap hasil belajar gambar 3 dimensi siswa SMK," J. Mech. Eng. Educ., vol. 2, no. 1, pp. 23-33, 2015.

[12] G. Kartikasari, "Pengaruh media pembelajaran berbasis multimedia terhadap motivasi dan hasil belajar materi sistem pencernaan manusia," Din. Penelit., vol. 16, no. 1, pp. 60-67, 2016.

[13] S. Srivastava, "A Study of Multimedia \& its Impact on Students 'Attitude," IEEE Int. Conf. Technol. Enhanc. Educ., pp. 1-5, 2012.

[14] A. P. Gilakjani, "A Study on the Impact of Using Multimedia to Improve the Quality of English Language Teaching," J. Lang. Teach. Res., vol. 3, no. 6, pp. 1208-1215, 2012.

[15] S. Khazai, M. Moradi, A. Tabataba, T. Higher, O. V. Boulevard, and H. Highway, "The effect of instructional multimedia on communicational skills learning of autism students," Futur. Med. Educ. J., vol. 21, pp. 29-36, 2017.

[16] F. Hanim, P. G. Universitas, and N. Malang, "Pengaruh Penggunaan Multimedia Pembelajaran Interaktif Penginderaan Jauh Terhadap Hasil Belajar Geografi,” $J$. Pendidik., vol. 1, no. 4, pp. 752-757, 2016. 